\title{
IL-10 down-regulates costimulatory molecules on Mycobacterium tuberculosis-pulsed macrophages and impairs the lytic activity of CD4 and CD8 CTL in tuberculosis patients
}

\author{
S. DE LA BARRERA*, M. ALEMÁN*, R. MUSELLA $†$, P. SCHIERLOH*, V. PASQUINELLI , V. GARCÍA \\ M. DEL C. SASIAIN**Departamento de Inmunología, Instituto de Investigaciones Hematológicas (IIHema), Academia Nacional de \\ Medicina, $\dagger$ División Tisioneumonología, Hospital F.J.Muñiz, $\ddagger$ Departamento de Microbiología, Parasitología e Inmunología y \\ Laboratorio de Inmunogenética, Facultad de Medicina, Universidad de Buenos Aires, Buenos Aires, Argentina
}

(Accepted for publication 21 June 2004)

\begin{abstract}
SUMMARY
Activation of T cells requires both TCR-specific ligation and costimulation through accessory molecules during $\mathrm{T}$ cell priming. IFN $\gamma$ is a key cytokine responsible for macrophage activation during Mycobacterium tuberculosis $(M t b)$ infection while IL-10 is associated with suppression of cell mediated immunity in intracellular infection. In this paper we evaluated the role of IFN $\gamma$ and IL-10 on the function of cytotoxic T cells (CTL) and on the modulation of costimulatory molecules in healthy controls and patients with active tuberculosis (TB). $\gamma$-irradiated- $M t b(\mathrm{i}-M t b)$ induced IL-10 production from CD $14^{+}$cells from $\mathrm{TB}$ patients. Moreover, $\mathrm{CD}^{+} \mathrm{T}$ cells of patients with advanced disease also produced IL-10 after i- $\mathrm{Mtb}$ stimulation. In healthy donors, IL-10 decreased the lytic activity of $\mathrm{CD}^{+}$and $\mathrm{CD} 8^{+} \mathrm{T}$ cells whereas it increased $\gamma \delta$-mediated cytotoxicity. Furthermore, we found that the presence of IL-10 induced a loss of the alternative processing pathways of antigen presentation along with a down-regulation of the expression of costimulatory molecule expression on monocytes and macrophages from healthy individuals. Conversely, neutralization of endogenous IL-10 or addition of IFN $\gamma$ to either effector or target cells from TB patients induced a strong lytic activity mediated by $\mathrm{CD}^{+} \mathrm{CTL}$ together with an up-regulation of CD54 and CD86 expression on target cells. Moreover, we observed that macrophages from TB patients could use alternative pathways for $\mathrm{i}-\mathrm{Mtb}$ presentation. Taken together, our results demonstrate that the presence of IL-10 during $M t b$ infection might contribute to mycobacteria persistence inside host macrophages through a mechanism that involved inhibition of MHC-restricted cytotoxicity against infected macrophages.
\end{abstract}

Keywords IL-10 macrophages coreceptors cytotoxicity tuberculosis

\section{INTRODUCTION}

In general, humans infected with M.tuberculosis (Mtb) display a strong delayed-type hypersensitivity response to the bacteria, as measured by the PPD skin test. Moreover, the majority of Mtbinfected individuals show a chronic bacterial burden. Activation of $\mathrm{T}$ cells, a process mediated through two critical signals provided by antigen presenting cells (APC), plays an important role in the protective immune response against $M t b$. The first signal, is Agspecific and requires TCR binding to the $\mathrm{MHC} / \mathrm{Ag}$ complex presented on the APC. The second signal, is Ag independent and

Correspondence: Dr María del Carmen Sasiain, II Hema. Inmunología, Academia Nacional de Medicina, Pacheco de Melo 3081, 1425 Buenos Aires, Argentina.

E-mail: msasiain@hematologia.anm.edu.ar involves the interaction of adhesion molecules and costimulatory molecules that bind to their respective ligands on $\mathrm{T}$ cells [1]. Thereafter, development of Th1 cytokine responses are enhanced by $\mathrm{CD} 40 / \mathrm{CD} 40 \mathrm{~L}$ interactions through IL-12 induction by macrophages and dendritic cells [2,3] and by augmentation of CD80/ CD86 expression $[4,5]$.

During active tuberculosis (TB), $\mathrm{CD}^{+}$and $\mathrm{CD} 8^{+} \mathrm{T}$ cells participate in the local host defense against $M t b$ but these cells are also involved in the immunopathology of the disease through the release of cytokines and/or the lysis of infected-target cells [6,7]. IFN $\gamma$ is a key cytokine that participates in macrophage activation mediating host defenses against $M t b$ [8]. In contrast, production of immunosuppressive/macrophage deactivating molecules upregulated during active $\mathrm{TB}$ contributes to the establishment of chronic mycobacterial infections $[9,10]$. In fact, overproduction of IL-10 by T cells has been associated with suppressive immu- 
nity and increased susceptibility to mycobacterial infection [11]. IL-10 has been reported to inhibit proliferation and IL-2 production by activated $\mathrm{T}$ lymphocytes by down-regulating the major histocompatibility complex (MHC) molecules [12]. In TB and leprosy, depressed IFN $\gamma$ responses seem to be mediated by IL-10 since $M t b$ and $M$. leprae elicit IL-10 production by macrophages $[13,14]$. Besides, it has been suggested that IL-10 produced by APC could play a major role as an autocrine regulator of macrophage activation by controlling the clearance of $M t b$ [12]. Therefore, triggering of IL-10 during the early stages of mycobacterial infection could strongly influence the generation of effector T cells during the subsequent adaptive immune response [12-14].

Antigen-specific $\mathrm{CD}^{+} \mathrm{T}$ lymphocytes are thought to be the main effector cells in $M t b$ infection through their ability to produce cytokines that activate macrophages $[6,15]$ and by contributing to maintain optimal $\mathrm{CD}^{+} \mathrm{T}$ cell responses [16]. On the other hand, $\gamma \delta$ T cells are readily activated by $M t b$ [17] and are potent sources of early IFN $\gamma$ production and competent cytotoxic effector cells. Therefore, $\gamma \delta \mathrm{T}$ cells might complement $\mathrm{CD} 4^{+}$and $\mathrm{CD}^{+} \mathrm{T}$ cells' functions during TB [18]. It is well known that the way in which particulate or soluble mycobacterial antigens are taken up by monocytes might influence the antigen processing pathway for $M t b$-specific $\mathrm{CD} 4^{+}$and $\mathrm{CD}^{+} \alpha \beta \mathrm{T}$ cells as well as for $\gamma \delta \mathrm{T}$ cell lines from $\mathrm{PPD}^{+}$healthy individuals. Actually, it has been demonstrated that particulate $M t b$ escapes the classical pathways for MHC class-I and class-II processing and, alternative pathways for antigen presentation in $\mathrm{PPD}^{+}$healthy individuals have been described [19,20].

In a previous study, we have demonstrated an inverse correlation between the impairment in the specific lytic activity of cells from TB patients and the severity of the disease [21]. However, this finding was not related to differences in the expression of MHC class I or class II molecules on APC. Given that binding of accessory molecules expressed on APC to their coreceptors on T cells plays an important role in T cell activation [22], we evaluated the role of IL-10 and IFN $\gamma$ on the function of CTL and as regulators of the expression of costimulatory molecules on APC. Moreover, we investigated the function of IL-10 and IFN $\gamma$ on cytotoxicity in human tuberculosis.

\section{MATERIALS AND METHODS}

\section{Patients}

Thirty patients with pulmonary tuberculosis were studied. Patients were diagnosed on the basis of the presence of recent clinical symptoms of tuberculosis, a positive sputum smear test for acid-fast bacilli confirmed by a positive culture of tuberculosis bacilli and characteristic chest radiograph. Informed consent for experimentation was obtained from patients according to the Ethics Committee of the Hospital Francisco J. Muñiz. All patients had active tuberculosis and 20 out of 30 were under multidrug treatment at the moment of the study (2-15 days). Pulmonary disease was classified according to the extent and type of X-ray findings into moderate (M) and advanced (A) tuberculosis according to the American Tuberculosis Society criteria. Routine blood tests were performed and patients who tested positive for human deficiency virus (HIV) or with concurrent infectious diseases were excluded. Patients were classified into two groups: M-TB: patients with moderate tuberculosis ( $n=10,28-53$ years) and A-TB: patients with advanced tuberculosis ( $n=20,22-68$ years). Twelve healthy individuals (25-60 years) were also studied as controls. Five of them were tuberculin skin positive $\left(\mathrm{PPD}^{+}\right)$.

\section{Mononuclear cells}

Heparinized blood was drawn and peripheral blood mononuclear cells (PBMC) were isolated by Ficoll-Hypaque gradient centrifugation [23]. Cells were collected from the interphase and suspended in RPMI 1640 tissue culture medium (Gibco Laboratory, NY, USA) containing gentamycin $(85 \mu \mathrm{g} / \mathrm{ml})$ and $15 \%$ heat inactivated fetal calf serum (FCS) (Gibco Laboratory, NY, USA) (complete medium).

\section{Antigen}

The $\gamma$-irradiated Mycobacterium tuberculosis H37-Rv strain (i$M t b)$ employed in this study was kindly provided by DrBelisle (Colorado University, Denver, CO, USA). Mycobacteria were resuspended in pyrogen free phosphate buffered (PBS), sonicated and adjusted to a concentration of $1 \times 10^{8}$ bacteria $/ \mathrm{ml}$.

\section{PBMC culture}

PBMC $\left(2 \times 10^{6}\right.$ cells $\left./ \mathrm{ml}\right)$ were cultured in Falcon 2063 tubes (Becton Dickinson, Lincoln, PK, NJ, USA) at $37^{\circ} \mathrm{C}$ in humidified $5 \%$ $\mathrm{CO}_{2}$ atmosphere, in complete medium with or without $\mathrm{i}-\mathrm{Mtb}$ $\left(1 \times 10^{6}\right.$ bacteria/ml, equivalent to $\left.5 \mu \mathrm{g} / \mathrm{ml}\right)$, IL-10 (10 ng/ml, Peprotech, Rocky Hill, NJ, USA), IFN $\gamma$ (100 U/ml, Peprotech) or a monoclonal antibody specific for human IL-10 (10 ng/ml, Peprotech). On day 6, i- $M t b$-stimulated and/or cytokine treated and control cells were washed thee times with RPMI 1640, suspended in complete medium $\left(2 \times 10^{6}\right.$ cells $\left./ \mathrm{ml}\right)$ and tested for their cytotoxic activity.

\section{Coculture of monocytes and lymphocytes}

Adherent cells (85-95\% monocytes) were obtained from PBMC by plastic adherence. $\mathrm{PBMC}\left(5 \times 10^{5}\right.$ cells/well $)$ were plated at the bottom of 24 well Falcon plates $\left(2 \mathrm{~h}\right.$ at $\left.37^{\circ} \mathrm{C}\right)$ and after removing the non adherent cells, monocytes were extensively washed with warm medium and cultured in complete medium in the presence of IL-10 (10 ng/ml) or IL-10 (10 ng/ml) plus IFN $\gamma(100 \mathrm{U} / \mathrm{ml})$ for $24 \mathrm{~h}$. Meanwhile, autologous nonadherent mononuclear cells were cultured in complete medium alone. Then, non adherent cells $\left(2 \times 10^{5}\right.$ cells $\left./ \mathrm{ml}\right)$ were added to the $24 \mathrm{~h}$ cultured monocytes and the cell suspensions were incubated for further 5 days in the presence of i-Mtb.

\section{Purification of $C D 4^{+} /$or $C D 8^{+} / \alpha \beta T C R^{+}$and $C D 4^{-} C D 8^{-} / \gamma \delta$ $\mathrm{TCR}^{+}$T lymphocytes}

Cultured $\mathrm{CD}^{+}$and $\mathrm{CD}^{+} \mathrm{T}$ cells expressing the $\alpha \beta \mathrm{TCR}$ and $\gamma \delta^{+} \mathrm{T}$ lymphocytes were isolated by negative selection with magnetic beads (Dynal, Oslo, Norway) from bulk PBMC or cocultures of monocytes and nonadherent cells. For $\mathrm{CD}^{+}$and $\mathrm{CD} 8^{+} \mathrm{T}$ cell enrichment, cells were treated first with anti- $\gamma \delta$ TCR (Pan $\gamma / \delta$, IgG1, clone Immun 510, Immunotech, Marseille, France) and anti-CD16 (IgG1, clone 3G8, Immunotech) monoclonal antibodies (MAb), followed by goat anti-mouse IgG-coated beads, and anti-CD8 or anti-CD4-coated beads (for $\mathrm{CD}^{+}$and $\mathrm{CD}^{+}$, respectively). For $\gamma \delta$ T cell enrichment cells were treated first with anti$\alpha \beta$ TCR (Pan $\alpha / \beta$, IgG2b, clone BMA 031, Immunotech) and anti-CD16 followed by goat-anti-mouse IgG-coated beads and anti-CD4- plus anti-CD8-coated beads. In both cases, cells were also depleted of B cells using anti-pan B-coated beads. Generally, one cycle of treatment was sufficient for an effective depletion as 
assessed by flow cytometry. Purity of isolated cells was $85-95 \%$ in each case. Isolated $\mathrm{CD}^{+}, \mathrm{CD}^{+}$and $\gamma \delta \mathrm{T}$ cells were resuspended in complete medium ensuring that the number of cell $/ \mathrm{ml}$ of each subset was the same as in total cultured PBMC in order to compare their lytic activity. Then $\mathrm{CD} 4^{+}, \mathrm{CD}^{+}$and $\gamma \delta \mathrm{T}$ lymphocytes were employed as effector cells in the cytotoxic assay.

\section{Target cells}

Monocytes were allowed to adhere to the bottom of 96 well flat bottom Falcon plates by incubation of $50 \mu \mathrm{l}$ of a PBMC $\left(1 \times 10^{6} /\right.$ $\mathrm{ml})$ suspension for $2 \mathrm{~h}$ at $37^{\circ} \mathrm{C}$. After removing nonadherent cells, cells remaining in the plates ( $10 \%$ of the original cell suspension) were extensively washed and incubated at $37^{\circ} \mathrm{C}$ in a humidified $5 \% \mathrm{CO}_{2}$ atmosphere for 6 days. On day 5, macrophages were pulsed overnight with i-Mtb $\left(1 \times 10^{6} \mathrm{bac} / \mathrm{ml}[5 \mathrm{mg} / \mathrm{ml}]\right)$ in the presence or absence of IL-10 $(10 \mathrm{ng} / \mathrm{ml})$ or IFN $\gamma(100 \mathrm{U} / \mathrm{ml})$. Macrophages kept under the same conditions but without addition of antigen were used as controls. On day 6 plates macrophages were washed with warm medium and labelled with $1 \mu \mathrm{Ci}$ of $\mathrm{Na}_{2}{ }^{51} \mathrm{CrO}_{4}$ (New England Nuclear, Boston, MA, USA) by incubation for $1 \mathrm{~h}$ at $37^{\circ} \mathrm{C}$. Then the cells were washed thee times and used as target cell.

\section{Cytotoxic assay}

$\mathrm{CD} 4^{+}, \mathrm{CD}^{+}$or $\gamma \delta \mathrm{T}$ cells effector cells were added in triplicate at a target cell ratio of $40: 1$ in $200 \mu \mathrm{l}$ final volume to ${ }^{51} \mathrm{Cr}$ labelled target cells $\left(5 \times 10^{3}\right)$ seeded into each well of 96 well microtitre plates (Corning, USA). Plates were centrifuged at $50 \times \mathrm{g}$ for $5 \mathrm{~min}$ and incubated at $37^{\circ} \mathrm{C}$ in $5 \% \mathrm{CO}_{2}$ for $4 \mathrm{~h}$. After centrifugation at $200 \times \mathrm{g}$ for $5 \mathrm{~min}, 100 \mu \mathrm{l}$ of supernatants were removed from each well. The radioactivity of supernatants and pellets was measured in a gamma counter. Results were expressed as percentage of cytotoxicity (\% Cx):

$$
\% \mathrm{Cx}=\frac{\mathrm{cpm} \text { exp }-\mathrm{cpm} \text { spont. release }}{\mathrm{cpm} \text { total }-\mathrm{cpm} \text { spont. release }}
$$

The radioactivity released from target cells incubated with complete medium alone was considered as spontaneous release. It ranged from 8 to $15 \%$. Total ${ }^{51} \mathrm{Cr}$ release was obtained by treating target cells with Triton X-100 5\% (Sigma, Chemical Co., St.Louis, MO, USA). In all cases, the cytotoxic assays performed with PBMC cultured in the absence of $\mathrm{i}-\mathrm{Mt} b$ or with macrophages not pulsed with antigen rendered negligible cytotoxicity $(0 \%-$ $6 \%$ ). Data presented in Tables 2 and 4 were obtained by subtracting the cytotoxicity against non antigen-pulsed macrophages from the experimental values determined using antigen-pulsed targets.

\section{Inhibition of antigen-presentation}

Inhibition of antigen processing was performed by incubating autologous macrophages with Chloroquine (400 $\mu \mathrm{M})$ (Sigma) o Brefeldin A (5 $\mu \mathrm{g} / \mathrm{ml})$ (Sigma) $30 \mathrm{~min}$ before addition of $\mathrm{i}-\mathrm{Mtb}$, IL-10 $(10 \mathrm{ng} / \mathrm{ml})$ or IFN $\gamma(100 \mathrm{U} / \mathrm{ml})$. After that, cells were coincubated overnight in the presence of inhibitors and i-Mtb. Then, macrophages were washed and labelled with ${ }^{51} \mathrm{Cr}$ and employed as target cells.

\section{Measurement of IFN $\gamma$ by ELISA}

PBMC were cultured in the presence or absence of i-Mtb $(5 \mu \mathrm{g} /$ $\mathrm{ml})$. After $48 \mathrm{~h}$ supernatants were frozen until their use. IFN $\gamma$ (Endogen) ELISA was performed according to the manufacturer's instructions. Briefly, flat bottom 96 well microtiter plates were coated with $100 \mu \mathrm{g} / \mathrm{ml}$ of mouse anti-human IFN $\gamma \mathrm{mAb}$ (Endogen \#M-700 A) at $5 \mathrm{~g} / \mathrm{ml}$ in sodium carbonate buffer (pH 9.6) and incubated overnight at $4^{\circ} \mathrm{C}$, followed by blocking with PBS containing $1 \%$ BSA for $1 \mathrm{~h}$ at room temperature. Samples and IFN $\gamma$ standard (human recombinant IFN $\gamma$, Endogen \#R-IFN $\gamma-\gamma$-50) were serially diluted and incubated at room temperature for $3 \mathrm{~h}$. Subsequently, biotinylated anti-IFN $\gamma \mathrm{mAb}$ (Endogen \#M-701-B) was added at $2 \mu \mathrm{g} / \mathrm{ml}$ for $1 \mathrm{~h}$ at room temperature. Avidin-peroxidase conjugate (Sigma, \#A-3151) was then added at $2 \mu \mathrm{g} / \mathrm{ml}$ for $30 \mathrm{~min}$ at room temperature. Peroxidase substrate solution (Kirkegaard \& Perry Laboratories Inc., Gaithersburg, MD, USA) was added and the plates were read in an ELISA reader (Cambridge Technology, Inc. Watertown, MA, USA) at a wavelength of $405 \mathrm{~nm}$. Washing steps (PBS containing $0 \cdot 1 \%$ BSA and $0 \cdot 05 \%$ Tween 20 ) were included between each step of the ELISA. A standard curve was made by plotting and regression analysis was applied. The IFN $\gamma$ concentration of each sample was calculated by regression analysis using the mean absorbance (average of triplicate readings) of the sample. The sensitivity of this assay was $10 \mathrm{pg} / \mathrm{ml}$.

\section{Immunofluorescence analysis}

Determination of $I L-10^{+}$cells. In order to determine the expression of intracytoplasmatic IL-10 in control and i-Mtb induced $\mathrm{CD}^{+}$effector cells or $\mathrm{CD} 14^{+}$monocytes, PBMC were cultured for $48 \mathrm{~h}$ with or without $\mathrm{i}-M t b$. Brefeldin A $(5 \mu \mathrm{g} / \mathrm{ml})$ was added to the PBMC cultures for the final $4 \mathrm{~h}$ of culture to block IL-10 secretion. Then cells were washed and $5 \times 10^{5}$ cells suspended in $100 \mu \mathrm{l}$ of PBS-azide were incubated with anti-CD3 or anti-CD14 MoAb (Ancell, Bayport, MN, USA) for $15 \mathrm{~min}$ at room temperature. Thereafter, the cells were fixed according to the manufacturer's instructions (IntraPrep ${ }^{\mathrm{TM}}$ permeabilization reagent, Immunotech). Then, cells were washed with PBS supplemented with $1 \%$ FCS and $0 \cdot 01 \%$ of azide (PBS-FCS-azide) and suspended in $100 \mu \mathrm{l}$ of PBS-FCS-azide. Phycoerythrin-conjugated antibody for IL-10 (Caltag, Burlinghame, CA, USA) was added together with $100 \mu \mathrm{l}$ of permeabilizing solution (IntraPrep). Cells were incubated for $30 \mathrm{~min}$ at $4^{\circ} \mathrm{C}$, washed once with PBS-FCSazide and finally suspended in Isoflow. The samples were analysed by flow cytometry as mentioned above. 20.000 events were acquired for each sample, gates were set with respect for the forward and side-scatter to exclude cell debris and apoptotic cells. Results are expressed as percentage of positive cells.

Expression of CD86, CD54, CD40 antigens on $C D 14^{+}$monocytes and macrophages. In order to evaluate the expression of CD86, CD54 and CD40 antigens on monocytes, PBMC were cultured for $18 \mathrm{~h}$ with or without $\mathrm{i}-M t b$ in the presence of either IL10 ( $\mathrm{N}$ controls) or IFN $\gamma$ (TB patients and $\mathrm{N}$ controls). On the other hand, monocytes isolated by plastic adherence from PBMC were cultured in 24 wells Falcon plates for 5 days with complete medium, then they were pulsed or not with i-Mtb and IL-10 or IFN $\gamma$ for further $18 \mathrm{~h}$. On day 6, macrophages were recovered from the plates. Plates were cooled for $3 \mathrm{~h}$ to facilitate the detachment of cells by vigorous pipetting with ice cold medium, cells were washed and then tested for their expression of CD86, CD54 and CD40. Either $18 \mathrm{~h}$ cultured-PBMC or 6 days cultured macrophages were incubated for $30 \mathrm{~min}$ at $4{ }^{\circ} \mathrm{C}$ with anti-human CD14 (FITC conjugated anti-CD14, Ancell, MN, USA or PEconjugated, Immunotech, France) and anti-human CD86 (B7-2/ PE, Ancell), anti-CD54 (ICAM-1/PE, Ancell) or anti-CD40 (FITC-anti-CD40, Ancell). FITC- or PE-labelled-isotype 
matched antibodies were also tested to evaluate nonspecific staining. Stained cells were analysed by flow cytometry by acquiring 20000 events. Results are expressed as relative fluorescence (RF):

$$
\mathrm{RF}=\frac{(\text { MFI specific antigen }- \text { MFI isotype antibody }) \times 100}{\text { MFI isotype antibody }}
$$

where MFI is mean fluorescence intensity.

\section{Statistics}

Comparisons of TB and N were performed using Student's $t$-test. Cytoxicity values obtained from the different subsets of effector cells of each individual were compared using the Wilcoxon signed rank test.

\section{RESULTS}

IL-10 impairs the lytic activity of $C D 4^{+}, C D 8^{+}$and $\gamma \delta T$ cells in healthy individuals

Since IL-10 could influence cytotoxic responses, we first investigated its role in the generation of $\mathrm{CD}^{+}, \mathrm{CD}^{+}$and $\gamma \delta^{+}$cytotoxic $\mathrm{T}$ lymphocytes (CTL). To do this, peripheral blood mononuclear cells (PBMC) from 10 healthy individuals $(\mathrm{N})$ were stimulated with $\mathrm{i}-M t b$ in the presence or absence of IL-10 for 6 days. Then, $\mathrm{CD} 4^{+}, \mathrm{CD}^{+}$and $\gamma \delta^{+} \mathrm{T}$ cells were isolated by negative selection and their ability to lyse autologous i-Mtb-pulsed macrophages was analysed. As shown in Table 1, the lytic activity from isolated $\mathrm{CD}^{+}$and $\mathrm{CD}^{+} \mathrm{T}$ cells was inhibited by exogenous addition of IL10 to the bulk culture during the induction stage in a dose dependent manner (data not shown). In contrast, the lytic activity of $\gamma \delta$ $\mathrm{T}$ cell was significantly enhanced in $\mathrm{N}$ individuals (Table 1 ). These results suggest that IL-10 impairs the lytic activity of CD4 and CD8 T cells while it enhances the lytic activity of $\gamma \delta \mathrm{T}$ cell in normal controls.

Pre-treatment of monocytes or macrophages with IL-10 modifies the CTL profile in PPD ${ }^{+} N$ controls

Considering that IL-10 markedly inhibits a broad spectrum of monocyte-macrophage functions including antigen-presentation [12], we next evaluated whether IL-10 could modulate monocyte

Table 1. Inhibitory effect of IL-10 on i-M.tuberculosis-induced CTL activity from healthy individuals

\begin{tabular}{lcccc} 
& & \multicolumn{3}{c}{ \% Cytotoxicity } \\
\cline { 3 - 5 } $\begin{array}{l}\text { PBMC inc. } \\
\text { with }\end{array}$ & $\begin{array}{c}\text { Macrophages } \\
\text { inc. with }\end{array}$ & $\mathrm{CD} 4$ & $\mathrm{CD} 8$ & $\gamma \delta \mathrm{T}$ \\
\hline i- $M t b$ & i- $M t b$ & $45 \pm 5$ & $28 \pm 5$ & $19 \pm 2$ \\
i- $M t b+\mathrm{IL}-10$ & i- $M t b$ & $26 \pm 5^{*}$ & $11 \pm 1^{*}$ & $28 \pm 4^{*}$ \\
\hline
\end{tabular}

PBMC from 10 healthy controls $(\mathrm{N})$ were incubated with i-Mtb with or without IL-10 $(10 \mathrm{ng} / \mathrm{ml})$ for 6 days. CD4, CD8 and $\gamma \delta \mathrm{T}$ cells were isolated by magnetic methods and used as effector cells. 5 day cultures of autologous macrophages were pulsed with i-Mtb $(18 \mathrm{~h})$ and then they were employed as target cells during the cytotoxic assay. Spontaneous release from i- $M t b$-stimulated macrophages was $8-15 \%$. Data were obtained subtracting spontaneous release to experimental values. Results are expressed as $\times-$ SEM. Statistical differences between percentage cytotoxicity from PBMC $-\mathrm{i}-M t b+$ IL-10 and percentage cytotoxicity from PBMC $-\mathrm{i}-M t b$ : $* P<0 \cdot 05$. functions during CTL development. Therefore, adherentmonocytes from $5 \mathrm{PPD}^{+}$healthy individuals $\left(\mathrm{N}-\mathrm{PPD}^{+}\right)$were preincubated with IL-10 for $24 \mathrm{~h}$, nonadherent autologous mononuclear cells were then added and cells were stimulated with i-Mtb. After 5 days, $\mathrm{CD} 4^{+}, \mathrm{CD}^{+}$and $\gamma \delta \mathrm{T}$ cells were isolated and antigen-specific cytotoxicity was determined employing i$M t b$-pulsed autologous macrophages. As shown in Fig. 1a, IL-10 pretreated monocytes inhibited $\mathrm{CD}^{+}$and $\mathrm{CD} 8^{+} \mathrm{CTL}$ activity while the lysis mediated by $\gamma \delta$ T cells was not modified. To determine whether this negative effect of IL-10 on monocytes could be modified by IFN $\gamma$, IL-10 and IFN $\gamma$ were simultaneously added to adherent-monocytes in culture. While the activity of $\mathrm{CD} 8^{+} \mathrm{CTL}$ was significantly increased by the coaddition of INF $\gamma$ neither $\mathrm{CD} 4^{+}$CTL nor $\gamma \delta \mathrm{T}$ CTL were significantly modified (Fig. 1a). These results demonstrate an impairment in the generation of MHC-restricted CTL activity after IL-10 treatment of human monocytes, suggesting that IL-10 might interfere with IFN $\gamma$ dependent pathways.

To evaluate whether IL-10 could modify the up-take or presentation of $M t b$ antigen to cytotoxic T cells, macrophages to be used as target cells, were pulsed overnight with i-Mtb in the presence of IL-10. As shown in Fig. 1b, this treatment induced a significant inhibition of $\mathrm{CD} 4^{+} \mathrm{CTL}$ activity and a complete abolishment of $\mathrm{CD}^{+} \mathrm{CTL}$ activity. However, a significant enhancement of $\gamma \delta$ T lytic activity was detected when IL-10 was present during $\mathrm{i}-\mathrm{M} t b$ up-take by macrophages from N-PPD ${ }^{+}$. Therefore, these results indicate that IL-10 might modulate the generation of effector cells and the presentation of Mtb antigens to cytotoxic T cells.

\section{$i$-Mtb-induced IL-10 production by $C D 14^{+}$monocytes and by $C D 3^{+} T$ cells in tuberculosis patients}

To determine whether $M t b$ stimulation could induce the generation of IL- $10^{+}$cells, PBMC from TB patients and N-PPD ${ }^{+}$were incubated with i- $M t b$ for $48 \mathrm{~h}$, and IL-10 production by CD14 ${ }^{+}$ and $\mathrm{CD}^{+}$cells was analized by flow cytometry. As shown in Tables 2, i- $M t b$-stimulated $\mathrm{CD} 14^{+}$cells from TB patients produced IL-10. On the other hand, no increase in IL-10 $0^{+}$cells was detected after $\mathrm{i}-\mathrm{Mtb}$ stimulation of PBMC from N-PPD ${ }^{+}$. The highest percentage of $\mathrm{IL}-10^{+} \mathrm{CD} 14^{+}$cells was detected among cells from A-TB patients which were significantly increased after i- $M t b$ stimulation. i-Mtb stimulation did not modify the levels of IL- $10^{+} \mathrm{CD} 14^{+}$in $\mathrm{M}-\mathrm{TB}$ patients and N-PPD ${ }^{+}$healthy individuals. Interestingly, IL- $10^{+} \mathrm{CD}^{+}$cells were only observed in $\mathrm{TB}$ patients and the highest percentage was detected in A-TB patients (Fig. 2).

\section{Effect of anti-IL-10 or IFN $\gamma$ on the modulation of the lytic} activity in tuberculosis patients

Previously we had demonstrated a loss of $\mathrm{CD}^{+} \mathrm{CTL}$ activity, an abrogation of $\mathrm{CD}^{+}$lytic activity and an enhancement of $\gamma \delta \mathrm{T}$ cytotoxic activity during severe pulmonary tuberculosis [21]. Since IL-10 inhibited the induction of MHC-restricted cytotoxic T cells in $\mathrm{N}-P P D^{+}$and considering the high percentage of IL-10 ${ }^{+}$ CD $14^{+}$cells detected in TB patients (Table 2), we next evaluated the role of IL-10 in the cytotoxicity during active TB. As shown in Table 3, the pattern of MHC and non-MHC-restricted CTL was related to the severity of the disease in accordance with previous data from our laboratory [21]. Neutralization of endogenous IL10 during the generation of CTL increased $\mathrm{CD} 4^{+}$and $\mathrm{CD} 8^{+}$lytic activity in tuberculosis patients (Table 3 ). Moreover, the addition of IFN $\gamma$ induced a significant increase in $\mathrm{CD} 4^{+} \mathrm{CTL}$ from A-TB and in $\mathrm{CD} 8^{+} \mathrm{CTL}$ in both groups of patients. Conversely, neither 
(a)

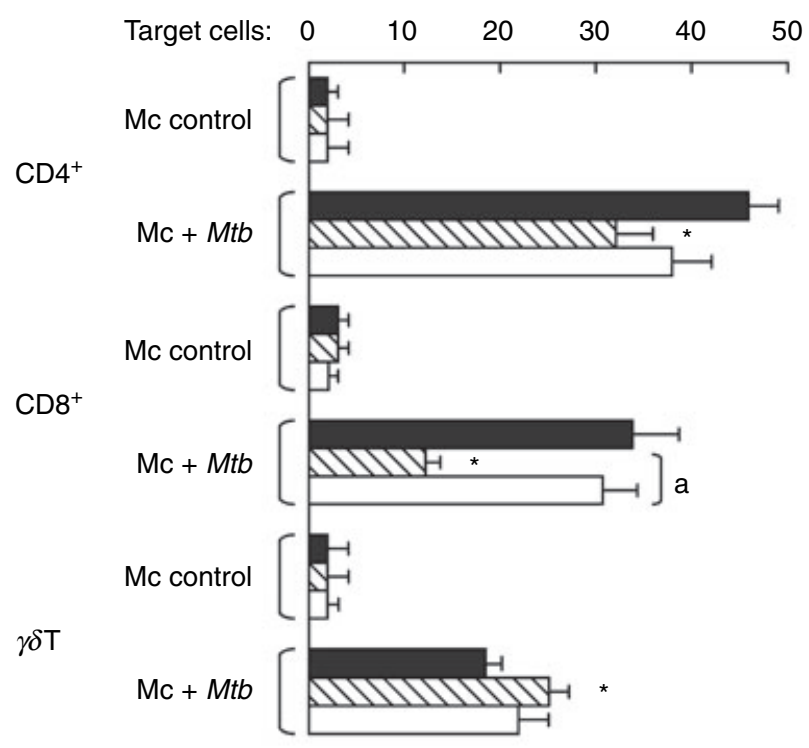

(b)

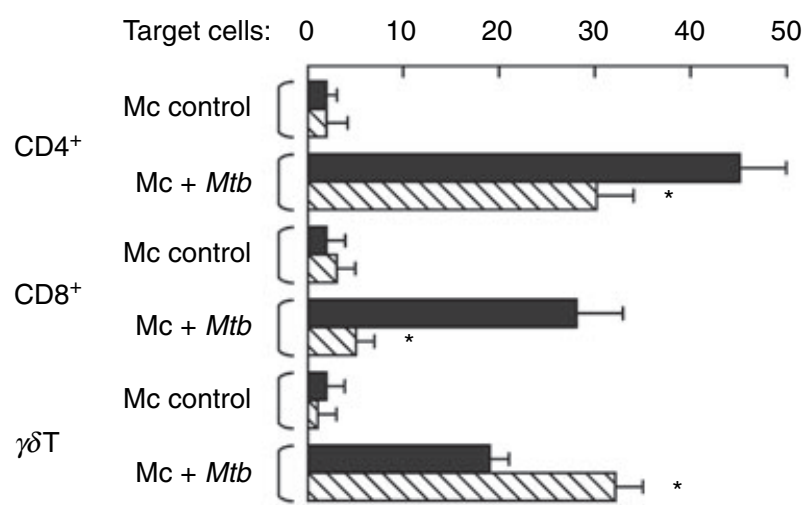

Fig. 1. Lytic activity of Mycobacterium tuberculosis-stimulated PBMC (a) Monocytes from $5 \mathrm{PPD}^{+}$normal individuals were allowed to adhere to 24 wells Falcon plates and cultured for $24 \mathrm{~h}$ with either complete medium alone ( $\square)$, IL-10 (ש) or IL-10 plus IFN $\gamma(\square)$. Then, autologous non adherent mononuclear cells $\left(2 \times 10^{5}\right.$ cells $\left./ \mathrm{ml}\right)$ were added to the $24 \mathrm{~h}$ cultured monocytes and the cell suspensions were incubated with medium alone or $\mathrm{i}-M t b$ for a further 5 days. On day $6, \mathrm{CD} 4^{+}, \mathrm{CD} 8^{+}$and $\gamma \delta \mathrm{T}$ lymphocytes were isolated from these monocytes/nonadherent cocultures and tested for their lytic activity against non pulsed (Mc control) and i-Mtb pulsed macrophages $(\mathrm{Mc}+\mathrm{Mtb})$. Results are expressed as percentage of cytotoxicity. Statistical differences:\% cytotoxicity from (nonadherent cells + IL-10 treated monocytes) versus $\%$ cytotoxicity from (nonadherent cells + non treated monocytes): ${ }^{*} P<0 \cdot 05 ; \%$ cytotoxicity from (nonadherent cells + IFN $\gamma$ and IL-10) versus \% cytotoxicity from (nonadherent cells + IL-10 treated monocytes): ${ }^{\mathrm{a}} P<0 \cdot 05$. (b) Monocytes from $5 \mathrm{PPD}^{+}$normal individuals were isolated from PBMC by plastic adherence and cultured for 5 days in complete medium. Then, macrophages were incubated for $18 \mathrm{~h}$ with or without $\mathrm{i}-\mathrm{Mtb}(\mathrm{Mc}+\mathrm{Mtb}$ and $\mathrm{Mc}$ control, respectively) in the absence ( $\mathbf{\square}$ ) or presence of IL-10 ( $\mathbb{Z}$ ). On day 6, macrophages were recovered from the plates and used as target cells in the cytotoxic assay. CD $4^{+}$, $\mathrm{CD}^{+}$and $\gamma \delta$ T lymphocytes were isolated from autologous PBMC cultured for 6 days with i- $M t b$ and employed as effector cells. Results are expressed as percentage of cytotoxicity. Statistical differences between percentage cytotoxicity employing IL-10 treated macrophages versus \% cytotoxicity employing nontreated macrophages: $* P<0 \cdot 05$.
Table 2. Percentage of $\mathrm{IL}-10^{+} \mathrm{CD} 14^{+}$and $\mathrm{IL}-10^{+} \mathrm{CD}^{+}$cells

\begin{tabular}{|c|c|c|c|c|}
\hline \multirow[b]{2}{*}{ PBMC from } & \multicolumn{2}{|c|}{$\%$ IL-10+ CD14+ cells } & \multicolumn{2}{|c|}{$\%$ IL-10+ CD3+ cells } \\
\hline & $\mathrm{C}$ & $\mathrm{i}-M t b$ & $\mathrm{C}$ & $\mathrm{i}-M t b$ \\
\hline M-TB & $4 \cdot 6-3 \cdot 2$ & $4 \cdot 8-0 \cdot 4 \dagger$ & $0 \cdot 2-0 \cdot 2$ & $0 \cdot 5-0 \cdot 3^{*}$ \\
\hline A-TB & $7 \cdot 8-1 \cdot 5+\neq$ & $12 \cdot 0-1 \cdot 4^{*}+\neq$ & $3 \cdot 9-1 \cdot 7+\ddagger$ & $5 \cdot 9-2 \cdot 3+*$ \\
\hline $\mathrm{N}$ & $4 \cdot 2-1 \cdot 1$ & $2 \cdot 9-0 \cdot 7$ & $0.05-0.05$ & $0 \cdot 1-0 \cdot 1$ \\
\hline
\end{tabular}

PBMC from 5 moderate (M-TB) and 6 advanced (A-TB) tuberculosis patients and 6 normal controls were cultured with medium (control, C) or with i- $M t b$ for $48 \mathrm{~h}$. Then, the percentage of IL- $10^{+} \mathrm{CD} 14^{+}$and IL- $10^{+} \mathrm{CD}^{+}$ cells was determined by flow cytometry. Results are expressed as percentage of double positive ( $\mathrm{x}-\mathrm{SEM})$. Statistical differences: $\mathrm{i}-M t b$-stimulated versus control cells: $* P<0 \cdot 05$; A-TB versus $\mathrm{N}: \dagger P<0 \cdot 05$, A-TB versus $\mathrm{M}$ TB: $\ddagger P<0 \cdot 05$.

Table 3. Modulatory effect of anti-IL-10 and IFN $\gamma$ on the induction stage of $\mathrm{i}-\mathrm{M} t \mathrm{~b}$ specific-CTL activity in patients with tuberculosis

\begin{tabular}{lllll}
\hline & & \multicolumn{3}{c}{$\%$ Cytotoxicity } \\
\cline { 3 - 5 } PBMC from & \multicolumn{1}{c}{$\begin{array}{c}\text { PBMC inc. } \\
\text { with }\end{array}$} & CD4 & CD8 & $\gamma \delta \mathrm{T}$ \\
\hline TB severity & & & & \\
Moderate & i- $M t b$ & $43 \pm 5$ & $24 \pm 3$ & $31 \pm 3$ \\
$(n=8)$ & i $-M t b+$ a-IL-10 & $53 \pm 4^{*}$ & $37 \pm 3^{*}$ & $38 \pm 3$ \\
& i $-M t b+$ IFN $\gamma$ & $50 \pm 5$ & $34 \pm 3^{*}$ & $38 \pm 3$ \\
Advanced & i $-M t b$ & $30 \pm 3$ & $9 \pm 1$ & $43 \pm 3$ \\
$(n=18)$ & i $-M t b+$ a-IL-10 & $44 \pm 4^{*}$ & $29 \pm 3^{*}$ & $43 \pm 3$ \\
& i- $M t b+$ IFN $\gamma$ & $42 \pm 3^{*}$ & $29 \pm 2^{*}$ & $42 \pm 3$ \\
& & & & \\
\hline
\end{tabular}

PBMC from 8 moderate (M-TB) and 18 advanced (A-TB) tuberculosis patients were incubated with $\mathrm{i}-\mathrm{Mtb}$ with or without anti-IL-10 $(10 \mathrm{ng} / \mathrm{ml})$ or IFN $\gamma(100 \mathrm{U} / \mathrm{ml})$ for 6 days. CD4, CD 8 and $\gamma \delta \mathrm{T}$ cells were isolated by magnetic beads and used as effector cells. Macrophages were pulsed with $\mathrm{i}-M t b(18 \mathrm{~h})$ and then these cells were employed as target cells during the cytotoxic assay. Results are expressed as mean - SEM. Statistical differences between percentage cytotoxicity from PBMC $+\mathrm{i}-\mathrm{M} t \mathrm{tb}+\mathrm{a}-\mathrm{IL}-10$ or IFN $\gamma$ and percentage cytotoxicity from PBMC $+\mathrm{i}-M t b: * P<0 \cdot 05$.

anti-IL-10 nor IFN $\gamma$ modified $\gamma \delta$ T cell-dependent cytotoxicity (Table 3). Furthermore, we found an inverse correlation between the production of IFN $\gamma$ against $\mathrm{i}-M t b$ and the severity of the disease (M-TB, $1390+396 \mathrm{pg} / \mathrm{ml}$; A-TB, $305+181 \mathrm{pg} / \mathrm{ml})$. However, neutralization of endogenous IL-10 or addition of IFN $\gamma$ during $\mathrm{i}-\mathrm{Mtb}$ up-take increased $\mathrm{CD} 8^{+} \mathrm{CTL}$ activity in $\mathrm{A}-\mathrm{TB}$ patients (Table 4).

\section{Effect of $i$-Mtb on the modulation of costimulatory molecules on} monocytes and macrophages

Given that overproduction of IL-10 by T cells has been associated with suppressed immunity [11] and that IL-10 produced by APC could act as an autocrine regulator of macrophage activation, we investigated whether the observed effects of IFN $\gamma$ and IL-10 on the lysis of $\mathrm{i}-M t b$-pulsed macrophages could be related to the modulation of $\mathrm{T}$ cell costimulatory molecules during CTL generation or i-Mtb-up-take. Therefore, either PBMC or 5 day

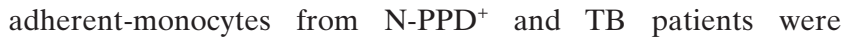


(a)

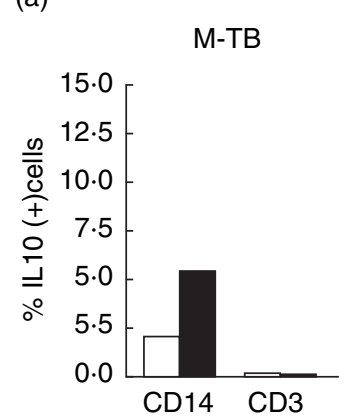

A-TB

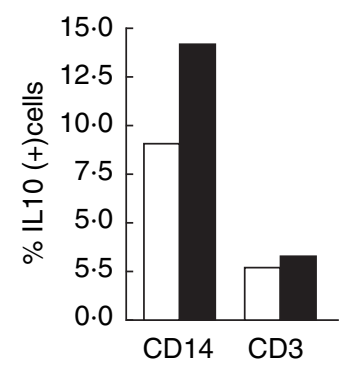

$\mathrm{N}$

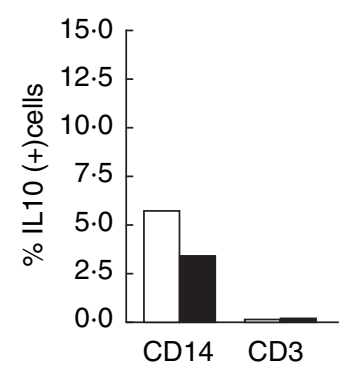

(b) Control CD14+cells $\mathrm{M}-\mathrm{TB}$

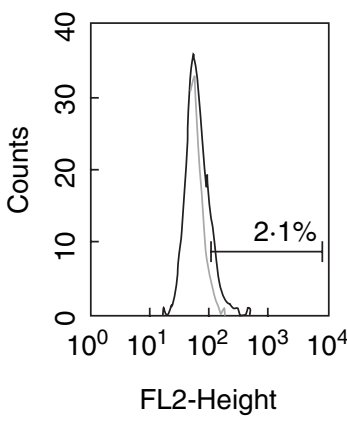

A-TB

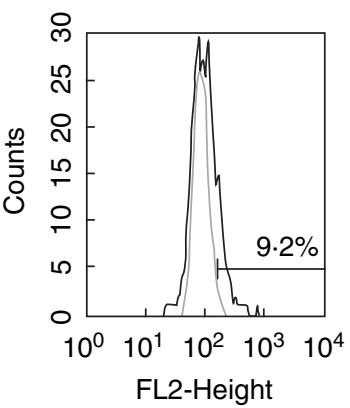

$\mathrm{N}$

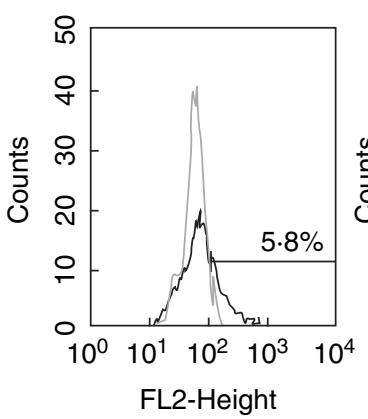

Mtb-CD14+cells

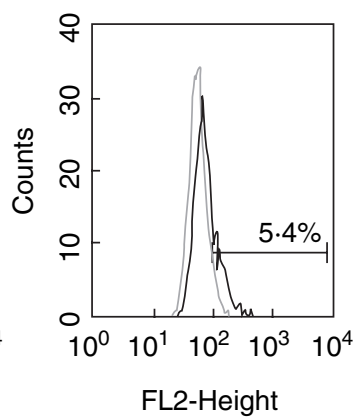

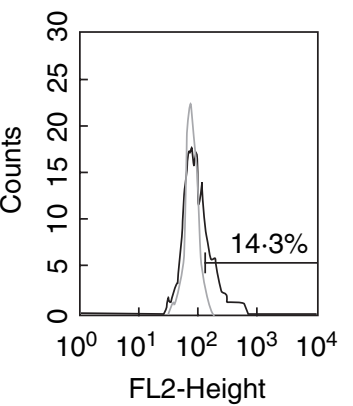

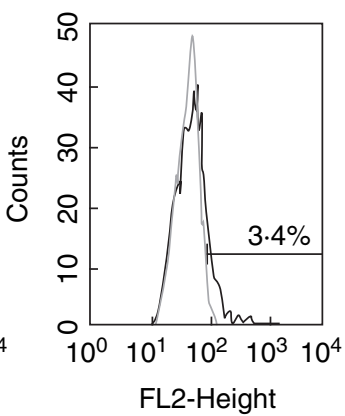

Fig. 2. $M t b$-induced IL-10 production by $\mathrm{CD} 14^{+}$monocytes and $\mathrm{CD} 3^{+} \mathrm{T}$ cells in tuberculosis patients. (a) PBMC from patients with moderate (M-TB) or advanced (A-TB) tuberculosis and $\mathrm{PPD}^{+}$normal individuals (N) were incubated in complete medium alone $(\square)$ or with i-Mtb (ם) for $48 \mathrm{~h}$, thereafter IL-10 produced by $\mathrm{CD}_{1} 4^{+}$and $\mathrm{CD}^{+}$cells was determined by flow cytometry. Results are expressed as percentage of IL-10 (+) cells in CD14 or CD3 populations (individual data are shown). (b) PBMC from M-TB, A-TB or N were cultured without (control) or i-Mtb for $48 \mathrm{~h}$ and then IL-10 producing monocytes were determined by flow cytometry. Black open histograms show IL-10 producing $\mathrm{CD} 14^{+}$monocytes while grey open histograms show the isotype-matched antibody. A representative example for each group is shown.

stimulated with i-Mtb in the presence or absence of IFN $\gamma$ or IL-10 for $18 \mathrm{~h}$, and cell surface expression of CD86, CD54 and CD40 on $\mathrm{CD} 14^{+}$cells was examined by flow cytometry.

As shown in Fig. 3, during maturation of monocytes to macrophages we detected an spontaneous increased expression of CD86 (in N-PPD ${ }^{+}$individuals) CD54 (in A-TB patients and N$\mathrm{PPD}^{+}$) and $\mathrm{CD} 40$ antigens (in TB patients and N-PPD ${ }^{+}$controls). i- $M t b$ down-regulated the expression of CD86 and CD54 on monocytes from M-TB patients and up-regulated the expression of CD86 on monocytes from N-PPD ${ }^{+}$. Moreover, i-Mtb stimulation also increased the levels of CD40 on monocytes from M-TB and N-PPD ${ }^{+}$. Furthermore, the addition of IFN $\gamma$ to i- $M t b$-stimulated monocytes, increased CD86 and CD40 levels on cells from TB patients. While IFN $\gamma$ did not modify the expression of costimulatory molecules on $\mathrm{i}-\mathrm{Mtb}$ stimulated $\mathrm{N}-\mathrm{PPD}^{+}$monocytes, the addition of IL-10 down-regulated the CD86 and CD40 levels
(Fig. 3). Like IFN $\gamma$, the neutralization of endogenous IL-10 in monocytes from TB patients increased the expression of CD86, CD54 and CD40 (Fig. 4). Besides, in macrophages pulsed with i$M t b$, we found an increased expression of CD86 in M-TB and N$\mathrm{PPD}^{+}$compared with control macrophages, while no changes in the levels of these molecules were observed by effect of IFN $\gamma$. However, IFN $\gamma$ did induce up-regulation of CD86 and CD54 on macrophages from A-TB. Furthermore, a down-regulation of CD86, CD40 and CD54 expression on N-PPD ${ }^{+}$macrophages was induced by IL-10 during i-Mtb up-take. Therefore, our data indicate that the down-regulation of the expression of costimulatory molecules by i-Mtb may be abrogated by the addition of IFN $\gamma$ or by neutralization of endogenous IL-10 (Fig. 4). Furthermore, the low expression of CD86 and CD54 on A-TB macrophages, suggests an incapacity of monocytes from TB patients to differentiate into macrophages. 
IL-10 inhibits alternative antigen-presentation pathways

It has been previously demonstrated that monocyte-derived macrophages from healthy individuals can process peptides derived from $M t b$ bacilli by alternate pathways and present them to $\mathrm{CD} 8^{+}$ and $\mathrm{CD} 4^{+} \mathrm{T}$ cells $[19,20]$. To explore whether the inability to generate MHC-restricted effector cells in TB patients could be related to differential use of antigen-presentation pathways, macrophages were treated with Brefeldin A or Chloroquine (inhibitors of classical MHC class-I and class-II antigen-presentation pathways, respectively), and after $2 \mathrm{~h}$, cells were pulsed with i$M t b$. As shown in Table 5, in TB patients and $\mathrm{N}$ controls $\gamma \delta \mathrm{T}$ cellmediated cytotoxicity was markedly inhibited by Brefeldin A. On the contrary, neither Brefeldin A nor Chloroquine inhibited CD4 ${ }^{+}$

Table 4. Modulation of CD4 and CD8 CTL activity by addition of anti-IL-10 or IFN $\gamma$ to i- $M t b$-pulsed macrophages

\begin{tabular}{lllll}
\hline & & \multicolumn{3}{c}{ \% Cytotoxicity } \\
\cline { 3 - 5 } $\begin{array}{l}\text { PBMC } \\
\text { from }\end{array}$ & $\begin{array}{c}\text { Macrophages } \\
\text { inc. with }\end{array}$ & $\mathrm{CD} 4$ & $\mathrm{CD} 8$ & $\gamma \delta \mathrm{T}$ \\
\hline TB & & & & \\
Moderate & & & & \\
$(n=8)$ & i- $M t b$ & $43 \pm 5$ & $24 \pm 3$ & $31 \pm 3$ \\
& i- $M t b+\mathrm{a}-\mathrm{IL}-10$ & $44 \pm 6$ & $26 \pm 3$ & $40 \pm 2$ \\
& i- $M t b+$ IFN $\gamma$ & $46 \pm 8$ & $31 \pm 3$ & $40 \pm 3$ \\
Advanced & & & & \\
$(n=20)$ & i- $M t b$ & $30 \pm 3$ & $10 \pm 3$ & $43 \pm 3$ \\
& i- $M t b+$ a-IL-10 & $42 \pm 5^{*}$ & $28 \pm 6^{*}$ & $42 \pm 3$ \\
& i- $M t b+$ IFN $\gamma$ & $42 \pm 4^{*}$ & $29 \pm 3^{*}$ & $39 \pm 4$ \\
\hline
\end{tabular}

$\mathrm{CD} 4, \mathrm{CD} 8$ and $\gamma \delta \mathrm{T}$ cells were isolated from 6 day i- $M t b$-cultured PBMC from $8 \mathrm{M}-\mathrm{TB}$ and $20 \mathrm{~A}-\mathrm{TB}$ and used as effector cells. Five day cultures of macrophages were pulsed $18 \mathrm{~h}$ with $\mathrm{i}-\mathrm{M} t \mathrm{~b}$ in the presence or absence of anti-IL-10 $(10 \mathrm{ng} / \mathrm{ml})$ or IFN $\gamma(100 \mathrm{U} / \mathrm{ml})$ and then they were employed as target cells during the cytotoxic assay. Results are expressed as mean \pm SEM. Statistical differences between percentage cytotoxicity from PBMC $+\mathrm{i}-M t b+\mathrm{a}-\mathrm{IL}-10$ or IFN $\gamma$ and percentage cytotoxicity from $\mathrm{PBMC}+\mathrm{i}-M t b: * P<0 \cdot 05$. and $\mathrm{CD}^{+}$-dependent cytotoxicity in $\mathrm{N}$ (Table 5), suggesting an effective use of alternate pathways to process i- $M t b$. Conversely, blockade of the classical class-I and class-II antigen presentation pathways significantly inhibited $\mathrm{CD}^{+}$and $\mathrm{CD} 4^{+}$-mediated cytotoxicity in TB patients. Only macrophages from M-TB patients and from healthy donors employed class-II alternative presentation pathway.

To explore whether IL-10 could be involved in the inhibition of the alternate pathways, 5 day-cultured macrophages from $\mathrm{N}$ control were first treated with IL-10, then $\mathrm{i}-M t b$ was added together with the inhibitors, and after $18 \mathrm{~h}$ the cells were used as target in cytotoxic assays. As shown in Table 5, pretreatment of macrophages with IL-10 modified the ability of $\mathrm{N}$ macrophages to employ the alternate pathways of i- Mtb processing/presentation to $\mathrm{CD} 4^{+}$or $\mathrm{CD}^{+} \mathrm{CTL}$. On the other hand, in TB macrophages previously incubated with anti-IL-10 or IFN $\gamma$, no inhibition of $\mathrm{CD}^{+} \mathrm{CTL}$ by Chloroquine and of $\mathrm{CD} 8^{+}$ CTL by Brefeldin A was observed. Taken together, these results suggest that IL-10 can modify the capacity of macrophages from TB patients to employ alternate pathways of antigen presentation.

\section{DISCUSSION}

Infection with $M t b$ is accompanied by a local inflammatory response where cytokines play an important role. In contrast to IFN $\gamma$, which is a key cytokine in the control of $M t b$ infection, IL10 is associated with suppression of CMI in TB patients [11]. In this study we evaluated the role of IL-10 on the modulation of the expression of costimulatory molecules during the development of CTL. Moreover, we analysed whether IL-10 participated in the lysis of i-Mtb-pulsed macrophages.

Our results showed that, in healthy individuals, IL-10 modified the lytic activity of $\mathrm{CD}^{+}, \mathrm{CD}^{+}$and $\gamma \delta \mathrm{T}$ cells. Furthermore, we found that IL-10 modulated the expression of costimulatory molecules on monocytes/macrophages and influenced the pathways for antigen presentation. Addition of IL-10 during CTL induction inhibited the ability to lyse i-Mtb-pulsed macrophages mediated by $\mathrm{CD}^{+}$and $\mathrm{CD} 8^{+}$cells but increased $\gamma \delta \mathrm{T}$ lytic activity.

Table 5. Differential inhibition of CD4 and CD8 CTL activity by Brefeldin A and Chloroquine in patients with tuberculosis and healthy individuals

\begin{tabular}{|c|c|c|c|c|c|c|c|c|c|c|}
\hline \multirow{2}{*}{$\begin{array}{l}\text { PBMC } \\
\text { from }\end{array}$} & \multirow{2}{*}{$\begin{array}{c}\text { Mac. } \\
\text { stimulated } \\
18 \text { h with }\end{array}$} & \multicolumn{3}{|c|}{$\begin{array}{l}\text { \% CD4-CTL against } \\
\text { macrophages treated } 1 \mathrm{~h} \text { with }\end{array}$} & \multicolumn{3}{|c|}{$\begin{array}{l}\text { \% CD8-CTL against } \\
\text { macrophages treated } 1 \mathrm{~h} \text { with }\end{array}$} & \multicolumn{3}{|c|}{$\begin{array}{l}\% \gamma \delta \text {-CTL against } \\
\text { macrophages treated } 1 \mathrm{~h} \text { with }\end{array}$} \\
\hline & & - & B & $\mathrm{C}$ & - & B & $\mathrm{C}$ & - & B & $\mathrm{C}$ \\
\hline M-TB & $\mathrm{i}-M t b$ & $45 \pm 4$ & $39 \pm 5$ & $44 \pm 5$ & $26 \pm 3$ & $11 \pm 5^{*}$ & $27 \pm 2$ & $30 \pm 7$ & $11 \pm 5^{*}$ & $33 \pm 6$ \\
\hline \multirow[t]{2}{*}{$(n=8)$} & $\mathrm{i}-M t b+\mathrm{a}-\mathrm{IL}-10$ & $45 \pm 4$ & $46 \pm 4$ & $49 \pm 5$ & $28 \pm 5$ & $29 \pm 5$ & $26 \pm 2$ & $40 \pm 2$ & $13 \pm 3$ & $27 \pm 5$ \\
\hline & $\mathrm{i}-M t b+\mathrm{IFN} \gamma$ & $48 \pm 4$ & $52 \pm 2$ & $53 \pm 4$ & $30 \pm 3$ & $29 \pm 5$ & $34 \pm 4$ & $41 \pm 3$ & $13 \pm 2$ & $29 \pm 4$ \\
\hline A-TB & $\mathrm{i}-M t b$ & $30 \pm 4$ & $32 \pm 3$ & $14 \pm 3^{*}$ & $10 \pm 1$ & $5 \pm 1 *$ & $13 \pm 1$ & $44 \pm 4$ & $10 \pm 2 *$ & $33 \pm 6$ \\
\hline \multirow[t]{2}{*}{$(n=16)$} & $\mathrm{i}-M t b+\mathrm{a}-\mathrm{IL}-10$ & $39 \pm 3$ & $38 \pm 5$ & $32 \pm 5$ & $26 \pm 4$ & $20 \pm 3$ & $26 \pm 2$ & $44 \pm 3$ & $11 \pm 3$ & $35 \pm 5$ \\
\hline & $\mathrm{i}-M t b+\mathrm{IFN} \gamma$ & $40 \pm 3$ & $41 \pm 3$ & $35 \pm 3$ & $25 \pm 3$ & $19 \pm 1$ & $27 \pm 4$ & $42 \pm 4$ & $10 \pm 3$ & $34 \pm 4$ \\
\hline $\mathrm{N}$ & $\mathrm{i}-M t b$ & $40 \pm 5$ & $36 \pm 3$ & $37 \pm 3$ & $25 \pm 4$ & $25 \pm 3$ & $29 \pm 2$ & $20 \pm 2$ & $7 \pm 2 *$ & $22 \pm 3$ \\
\hline$(n=10)$ & $\mathrm{i}-M t b+\mathrm{IL}-10$ & $24 \pm 5$ & $20 \pm 1$ & $13 \pm 3 *$ & $16 \pm 1$ & $5 \pm 3 *$ & $14 \pm 2$ & $32 \pm 4$ & $5 \pm 3$ & $27 \pm 5$ \\
\hline
\end{tabular}

PBMC from patients with tuberculosis and $\mathrm{N}$ controls were incubated with i-Mtb for 6 days and then used as effector cells. Five day cultures autologous macrophages were pulsed $(18 \mathrm{~h})$ with i-Mtb in the presence or absence of either a-IL-10 or the cytokines (CKs) IFN $\gamma$ for patients or IL-10 for N controls, and Brefeldin A (B) or Chloroquine (C) as described in Materials and Methods. Then, macrophages were used as target cells in the cytotoxic assay. Results are expressed as mean + SEM. Statistical differences between percentage cytotoxicity against macrophages $+\mathrm{i}-\mathrm{Mt} b+\mathrm{anti}-\mathrm{IL}-10 / \mathrm{CKs}+\mathrm{Brefeldin}$ A or Chloroquine and percentage cytotoxicity against macrophages $+\mathrm{i}-M t b+$ anti-IL-10/CKs without inhibitors: $* P<0 \cdot 05$. 
Recently isolated monocytes

(a)

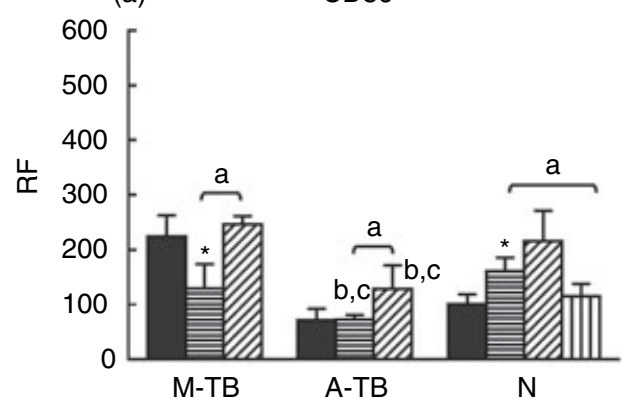

(b)

CD54

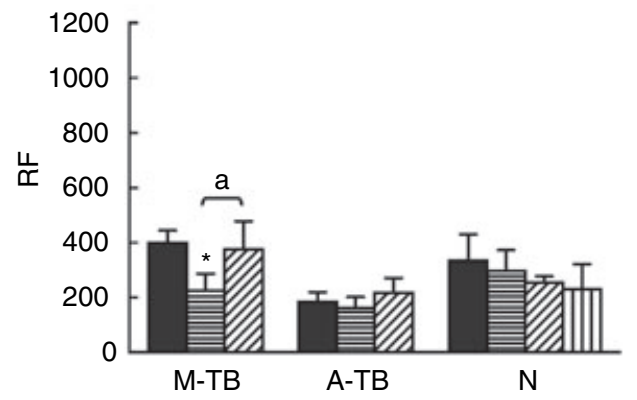

(c)

CD40

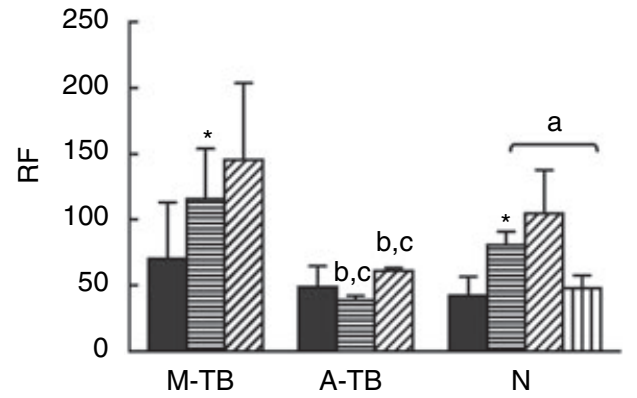

5-days cultured macrophages

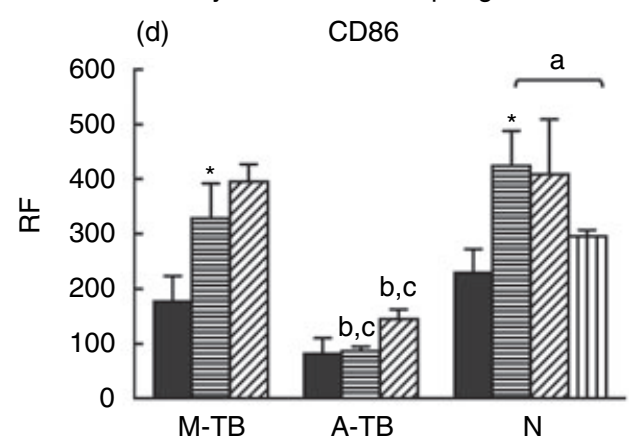

(e)

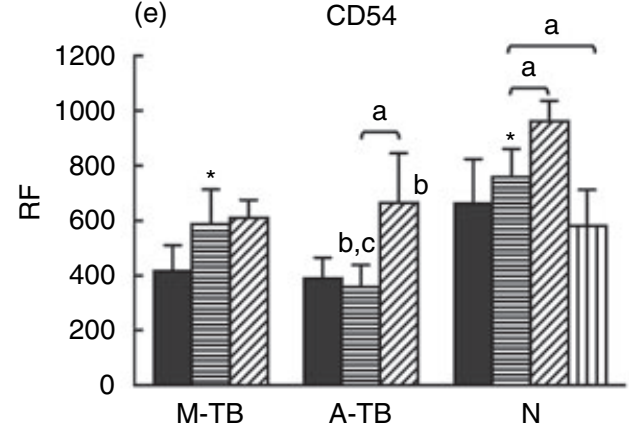

(f)

CD40

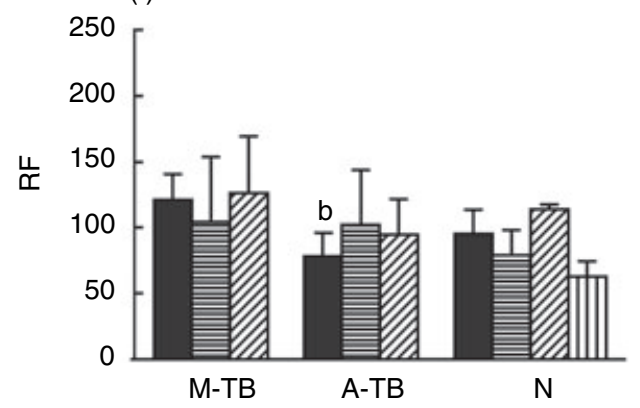

Fig. 3. $M t b$ modulates $\mathrm{T}$ cell costimulatory molecules on monocytes and macrophages. Recently isolated PBMC (a-c) or 5 day adherentmonocytes (d-f) from $4 \mathrm{M}-\mathrm{TB}, 6 \mathrm{~A}-\mathrm{TB}$ and $5 \mathrm{~N}-\mathrm{PPD}^{+}$were cultured for $18 \mathrm{~h}$ in complete medium alone, with i-Mtb or with i-Mtb plus IFN $\gamma$ or IL-10, and cell surface marker expression of CD86 (a,d), CD54 (b,e) and CD40 (c,f) on CD14 cells was examined by flow cytometry. Open histograms represent the monocytes stained with specific antibodies; grey dotted histograms represent the respective isotype control. Results are expressed as relative fluorescence (RF) (mean - SEM) as mentioned in Materials and Methods. Statistical differences: RF from i-Mtb-pulsed macrophages versus RF from control macrophages: $* P<0 \cdot 05$; RF from IFN $\gamma$ or IL-10 treated-i- $M t b$ pulsed macrophages versus RF from i-Mtb-pulsed macrophages: ${ }^{\mathrm{a}} P<0 \cdot 05$; RF A-TB versus $\mathrm{N}:{ }^{\mathrm{b}} P<0 \cdot 05$, A-TB versus $\mathrm{M}-\mathrm{TB}:{ }^{\mathrm{c}} P<0 \cdot 05$.

Given that we did not find a high percentage of CD $14^{+} \mathrm{IL}-10^{+}$or $\mathrm{CD}^{+} \mathrm{IL}-10^{+}$cells in $\mathrm{N}-\mathrm{PPD}^{+}$in response to $\mathrm{i}-\mathrm{Mtb}$, our results suggest that the IL-10 would be responsible for the observed effect on the lytic activity. Accordingly, in TB patients where $\mathrm{CD}^{+} \mathrm{IL}-10^{+}$ cells were detected, neutralization of IL-10 led to an increase in the lytic activity of $\mathrm{CD} 4^{+}$and $\mathrm{CD} 8^{+}$cells, but it did not modify $\gamma \delta \mathrm{T}$ activity. Moreover, neither IL-10 nor IL-10 plus IFN $\gamma$ affected the $\gamma \delta \mathrm{T}$-mediated lytic activity on monocytes from N-PPD ${ }^{+}$suggesting that $\gamma \delta$ cells may represent an in vivo polarized type- 1 population [24] expanded through a pathway that does not require antigen uptake, processing or known presenting molecules [25]. Therefore, the early production of IL-10 detected in response to i- $M t b$, could be related to the high $\gamma \delta$ T lytic activity in TB patients.

Costimulatory molecules are important for the initiation and maintenance of an immune response [1-5,22,26]. Our results showed a decrease in the expression of CD86 and CD40 on mono- cytes from $\mathrm{PPD}^{+}$healthy donors pretreated with IL-10 upon i- $M t b$ stimulation, which would be affecting the lytic activity of $\mathrm{CD}^{+}$ and $\mathrm{CD}^{+}$CTL. CD86, a molecule constitutively expressed on APC, plays a key role in early interactions between APC and T cells $[26,27]$ and has been shown to be the major CD28 costimulatory ligand in the clonal expansion of Ag-specific cells [28]. Furthermore, CD86 delivered as vaccine adjuvant was shown to play a prominent role in the Ag-specific induction of CD8 ${ }^{+} \mathrm{CTL}$ [29]. In accordance, we found that the up-regulation of CD86 on i-Mtbstimulated monocytes from $\mathrm{N}-\mathrm{PPD}^{+}$correlated with a strong $\mathrm{CD}^{+}$lytic activity. Enhanced expression of B7 molecules on APC (due to CD40/CD40L interactions) results in the induction of NF- $\kappa$ B, STAT-3 activation [30-32], and cytokine production, including IL-10 [33]. However, CD40 may also redirect the cytokine response towards a Th1 profile through stimulation of IL-12 which leads to IFN $\gamma$ production [34]. Our results showed 
(a)

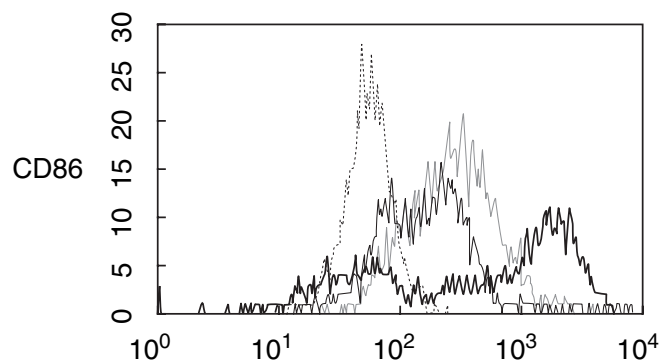

(b)

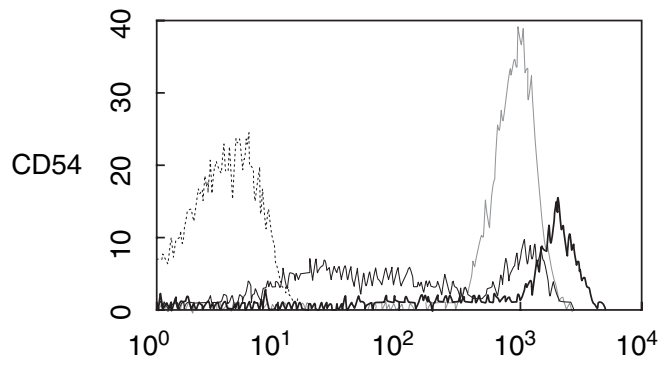

(c)

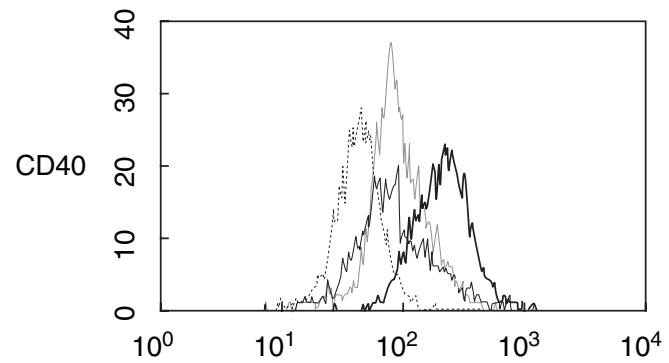

(d)

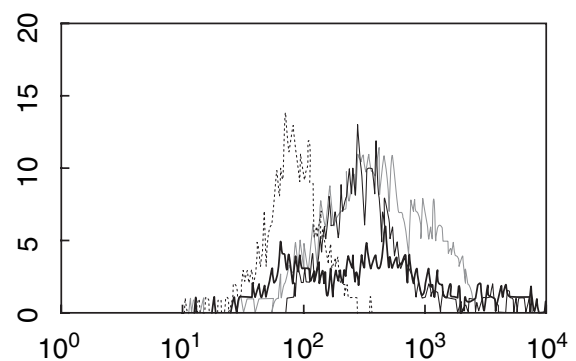

(e)

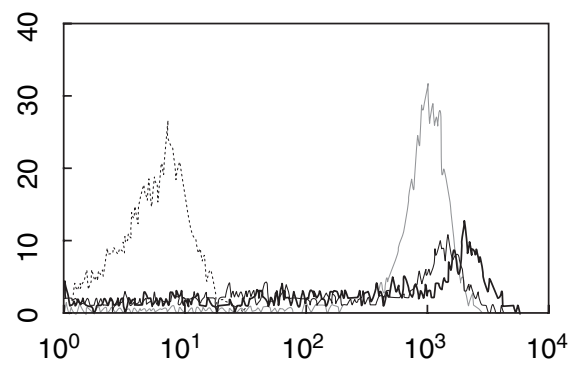

(f)

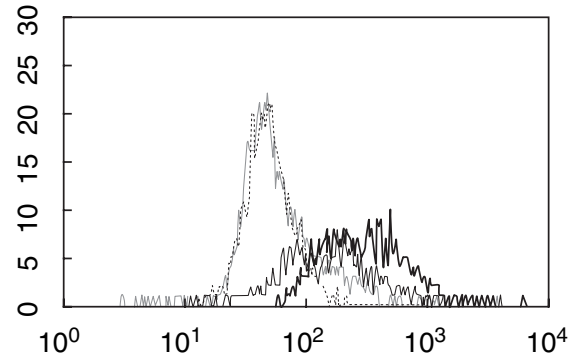

Fig. 4. Recently isolated PBMC from $3 \mathrm{M}-\mathrm{TB}(\mathrm{a}-\mathrm{c})$ and $3 \mathrm{~A}-\mathrm{TB}(\mathrm{d}-\mathrm{f})$ were cultured during $18 \mathrm{~h}$ in medium alone (- - - -), i-Mtb ( $\longrightarrow$ ) or with i-Mtb and anti-IL-10 MAb (—). Then, the surface expression of CD86, CD54 and CD40 on CD14 cells was examined by flow cytometry. $\square$ the monocytes stained with specific antibodies; $\mathbf{\square}$ the respective isotype control. A representative example for each group is shown.

up-regulation of CD40 on monocytes from N-PPD ${ }^{+}$upon i-Mtb stimulation, suggesting that the signals triggered by the bacteria in monocytes (regarding the production of IL-10), might be overridden by the IFN $\gamma$ produced by N-PPD ${ }^{+}$cells. In agreement, the addition of IFN $\gamma$ to IL-10 pretreated monocytes overcame the inhibition of $\mathrm{CD}^{+}$cells lytic activity increasing the $\mathrm{CD} 4^{+}$lytic activity. Similar to healthy donors, $\mathrm{i}-\mathrm{Mtb}$ increased the expression of CD40 in CD14 ${ }^{+}$cells from M-TB patients. Conversely, neither i- $M t b$ nor IFN $\gamma$ modified the low expression of CD40, CD86 and CD54 molecules on monocytes from A-TB patients. It has been demonstrated that mice deficient in CD40L achieved Th1 protection against $M t b$ [35]. However, depressed expression of CD40L in TB patients correlated with reduced IFN $\gamma$ production and blockade of CD40 in N-PPD ${ }^{+}$reduced IFN $\gamma$ production [36]. Our results showed that the low $\mathrm{CD} 40$ expression in control and i$M t b$-stimulated monocytes from A-TB patients, correlated with reduced IFN $\gamma$ levels and low expression of CD86. Together, these results suggest that diminished CD40 expression on monocytes during i-Mtb stimulation might contribute to reduce IFN $\gamma$ production, affecting the lytic activity. Therefore, IL-10 would regulate the lytic activity of CTL at least in part through the down-regulation of costimulatory molecules during CTL induction.

In macrophages from N-PPD ${ }^{+}$, the presence of IL-10 during the uptake of $\mathrm{i}-\mathrm{Mtb}$ inhibited the $\mathrm{CD}^{+}$-cytotoxicity but increased the $\gamma \delta$ T-mediated lytic activity. Moreover, IL-10 induced a downregulation of CD86, CD54 and CD40 expression on macrophages. In agreement with these results, the neutralization of endogenous IL-10 in A-TB patients increased the lytic activity of $\mathrm{CD}^{+} \mathrm{T}$ cells. Thus, the lowest expression of CD86 and CD54 correlated with the highest amount of CD14 ${ }^{+} \mathrm{IL}-10^{+}$cells and the lowest IFN $\gamma$ production in A-TB patients, suggesting that endogenous IL-10 might participate in delaying the differentiation of monocytes to macrophages. Moreover, addition of IFN $\gamma$ up-regulated the expression of CD86 and CD54 on macrophages from A-TB patients and improved the lytic activity from CD $8^{+}$cells. CD54 has a crucial role in granuloma formation in $M t b$-infected mice $[37,38]$. In addition, CD54 is a strong driver of CTL induction and $\mathrm{CD}^{+}$effector functions and its expression induces IFN $\gamma$ production by costimulated T cells [39]. In the current study, we showed that IFN $\gamma$ increased CD54 expression on i- $M t b$ stimulated monocytes from M-TB patients or on macrophages from A-TB patients 
leading to enhancement of MHC-restricted lytic activity. These results could explain in part the improvement in clinical symptoms observed in TB patients exposed to r-IFN $\gamma$ aerosols in vivo [40]. Therefore, our data indicate that if IFN $\gamma$ is present at the site of infection, as in M-TB patients, the expression of CD54 molecules on APC could provide costimulatory signals to $\mathrm{CD} 8^{+} \mathrm{CTL}$ [41,42]. Hence, the coexpression of CD86 and CD54 would amplify the MHC-restricted cytotoxic activity contributing to the lysis of infected cells.

Finally, our results regarding the antigen presentation pathways for $\mathrm{i}-\mathrm{Mtb}$ in $\mathrm{N}$ controls are in accordance with Balaji \& Boom [19] and Canaday et al. [20] who demonstrated alternate pathways for $M t b$ presentation to MHC-restricted cytotoxic T cells. Neither Brefeldin A nor Chloroquine inhibited the presentation to $\mathrm{CD}^{+}$and $\mathrm{CD} 4^{+} \mathrm{CTL}$. Nevertheless, if IL-10 was present during i-Mtb uptake, processing of $M t b$-antigens followed the classical presentation pathways. As in $\mathrm{N}$ controls, macrophages from TB patients are able to use the class-I and class-II alternate presentation pathways when endogenous IL-10 is neutralized or IFN $\gamma$ is added. Therefore, our data suggest that IL-10 may also participate in the modification of $M t b$ processing. Considering that IFN $\gamma$ and IL-10 signalling are similar [43], our data suggest that mycobacteria could have developed strategies to inhibit IFN$\gamma$ signalling [44] or to enhance IL-10 triggering, by modifying the processing pathway of the bacteria through inhibition of alternate MHC-class I and class II processing pathways. In this way, this pathogen would successfully persist inside host macrophages. However, other mechanisms, such prolonged exposure to pathogen-associated molecular patterns that signal through Toll-like receptors may also be involved $[45,46]$.

In conclusion, either inappropriate IL-10 expression or signalling in $\mathrm{PPD}^{+}$individuals contribute to the progression of tuberculosis by inhibiting IFN $\gamma$ signalling and by the down- regulation of costimulatory molecules. Moreover, the ineffective maturation from monocytes to macrophages may also be related to the presence of IL-10 at the site of infection, preventing the differentiation of these cells to dendritic cells $[47,48]$, leading to ineffective specific cytotoxicity and favouring the perpetuation of the disease.

\section{ACKNOWLEDGEMENTS}

We thank the medical staff of División Tisioneumonología of Hospital F.J.Muñiz, for their great help providing clinical samples from patients with tuberculosis. This work was supported by grants from the Consejo Nacional de Investigaciones Científicas y Técnicas (CONICET, PIP 0711/98) and from the Agencia Nacional de Promoción Científica y Tecnológica (ANPСуТ, 05-04816).

\section{REFERENCES}

1 Greenfield EA, Nguyen KA, Kuchoo VK. CD28/B7 costimulation: a review. Crit Rev Immunol 1998; 18:389-418.

2 McDyer JF, Goletz TJ, Thomas E, June CH, Seder RA. CD40 ligand/ CD40 stimulation regulates the production of IFN $\gamma$ from human peripheral blood mononuclear cells in an IL-12 and/or CD28dependent manner. J Immunol 1998; 160:1701-7.

3 Stüber E, Strober W, Neurath M. Blocking the CD40L/CD40 interaction in vivo specifically prevents the priming of $\mathrm{T}$ helper 1 cells through the inhibition of interleukin 12 secretion. J Exp Med 1996; 183:693-8.

4 Morse MA, Lyerly K, Gilboa E, Thomas E, Nair SK. Optimization of the sequence of antigen loading and CD40-ligand induced maturation of dendritic cells. Cancer Res 1998; 58:2965-8.
5 Yang Y, Wilson JM. CD40 ligand-dependent T cell activation requirement of B7-CD28 signalling though CD40. Science 1996; 273:1862-4.

6 Tan JS, Canady DH, Boom WH, Balaji KN, Schwander SK. Human alveolar T lymphocyte response to Mycobacterium tuberculosis. Role for $\mathrm{CD} 4+$ and $\mathrm{CD} 8+$ cytotoxic $\mathrm{T}$ cells and relative resistance of alveolar macrophages to lysis. J Immunol 1997; 159:290-7.

7 Flynn JL, Goldstein MM, Triebold KJ, Koller B, Bloom BR. Major histocompatibility class I restricted $\mathrm{T}$ cells are required for resistance to Mycobacterium tuberculosis infection. Proc Natl Acad Sci USA 1992; 89:12013-7.

8 Flynn JL, Chan J, Triebold KJ, Dalton DK, Stewart T, Bloom BR. An essential role for Interferon- $\gamma$ in resistance to Mycobacteriun tuberculosis infection. J Exp Med 1993; 178:2249-54.

9 Toosi Z, Gogate P, Shiratsuchi H, Young T, Ellner JJ. Enhanced production of TGF- $\beta$ by blood monocytes from patients with active tuberculosis and presence of TGF- $\beta$ in tuberculosis granulomatous lung lesions. J Immunol 1995; 154:465-73.

10 Dlugovizky DA, Torrez-Morales A, Rateni L, Farroni MA, Largacha O, Molteni O, Bottasso O. Circulating profile of Th1 and Th2 cytokines in tuberculosis patients with different degrees of pulmonary involvement. FEMS Immunol Med Microbiol 1997; 18:203-7.

11 Boussiotis VA, Tsai EY, Yunis EJ, Thim S, Delgado JC, Dascher CC, Berezovskaya A, Rousset D, Reynes JM, Goldfeld AE. IL-10producing $\mathrm{T}$ cells suppress immune responses in anergic tuberculosis patients. J Clin Invest 2000; 105:1317-25.

12 Moore KW, de Wall Malefyt R, Coffman RL, O'Garra A. Interleukin10 and the Interleukin-10 receptor. Annu Rev Immunol 2001; 19:683765.

13 Shaw T, Thomas LH, Friedland JL. Regulation of IL-10 secretion after phagocytosis of Mycobacterium tuberculosis by human monocytic cells. Cytokine 2000; 12:483-6.

14 Sieling PA, Abrams JS, Yamamura M, Salgame P, Bloom BR, Rea TH, Modlin RL. Immunosuppressive roles for IL-10 and IL-4 in human infection. In vitro modulation of $\mathrm{T}$ cell responses in leprosy. J Immunol 1993; 150:5501-10.

15 Orme I, Roberts A, Grieffen J, Abrams JS. Cytokine secretion by CD4+ T lymphocytes acquired in response to Mycobacterium tuberculosis infection. J Immunol 1993; 151:518-25.

16 Serbina N, Lazarevic V, Flynn J. CD4 ${ }^{+} \mathrm{T}$ cells are required for the development of cytotoxic CD8+ T cells during Mycobacterium tuberculosis infection. J Immunol 2001; 167:6991-00.

17 Kabelitz D, Bender A, Schondelmaier S, Schoe B, Kaufmann SHE. A large fraction of human peripheral blood $\gamma / \delta \mathrm{T}$ cells is activated by Mycobacterium tuberculosis but not by its $65-\mathrm{kD}$ heat shock protein. J Exp Med 1990; 171:667-79.

18 Tsukaguchi K, Balaji KN, Boom WH. CD4+ $\alpha \beta$ T cell and $\gamma \delta$ T cell responses to Mycobacterium tuberculosis. similarities and differences in antigen recognition, cytotoxic effector function, and cytokine production. J Immunol 1995; 154:1786-96.

19 Balaji K, Boom WH. Processing of Mycobacterium tuberculosis by human monocytes for $\mathrm{CD} 4+\alpha \beta$ and $\gamma \delta$ T cells role of particulate antigen. Infect Immun 1998; 66:98-106.

20 Canaday DH, Ziebold Ch, Noss EH, Chervenak KA, Harding CV, Boom WH. Activation of human CD $8+\alpha \beta \mathrm{TCR}+$ cells by Mycobacterium tuberculosis via an alternate class I MHC antigen-processing pathway. J Immunol 1999; 162:372-9.

21 de la Barrera SS, Finiasz M, Frias A et al. Specific lytic activity against mycobacterial antigens is inversely correlated with the severity of tuberculosis. Clin Exp Immunol 2003; 132:450-61.

22 Damle NK, Klussmann K, Linsley PS, Aruffo A. Differential costimulatory effects of adhesion molecules B7, ICAM-1, LFA-3 and VCAM1 on resting and antigen-primed CD4+ T lymphocytes. J Immunol 1992; 148:1989-92.

23 Boyum A. Isolation of mononuclear cells and granulocytes from human blood. Scand J Clin Invest 1968; 97:77-89.

24 Dagna L, Iellem A, Biswas P et al. Skewing of cytotoxic activity and chemokine production, but not of chemokine receptor expression, in 
human type-1/-2 gamma delta T lymphocytes. Eur J Immunol 2002; 32:2934-43.

25 Morita CT, Beckman EM, Bukowski JF, Tanaka Y, Band H, Bloom BR, Golan DE, Brenner MB. Direct presentation of nonpeptide prenyl pyrophosphate antigens to human gamma delta $\mathrm{T}$ cells. Immunity 1995; 3:495-507.

26 Van Gool SW, Vandenberghe P, de Boer M, Ceuppens JL. CD80, CD86 and CD40 provide accessory signals in a multiple-step T-cell activation model. Immunol Rev 1996; 153:47-83.

27 Freeman GJ, Borriello F, Hodes RJ et al. Murine B7-2, an alternative CTLA4 counter-receptor that costimulates $\mathrm{T}$ cell proliferation and interleukin 2 production. J Exp Med 1993; 178:2185-92.

28 Bluestone JA. New perspectives of CD28-B7-mediated T cell costimulation. Immunity 1995; 2:555-9.

29 Kim JJ, Bagarazzi ML, Trivedi $\mathrm{N}$ et al. Engineering of in vivo immune responses to DNA immunization via co-delivery of costimulatory molecule genes. Nat Biotechnol 1997; 15:641-6.

30 Ranheim EA, Kipps TJ. Activated T cells induce expression of B7/BB1 on normal or leukemic B cells through a CD40-dependent signal. J Exp Med 1993; 177:925-35.

31 Arinobu Y, Sugimoto R, Akaiwa M, Arima K, Otsuka T, Hamasaki N, Izuhara K. Augmentation of signal transducer and activation of transcription (STAT) 6 and STAT3 expression in stimulated B and T cells. Biochem Biophys Res Commun 2000; 277:317-24.

32 Francis DA, Karras JG, Ke XY, Sen R, Rothstein TL. Induction of the transcription factors NF-kappa B, AP-1 and NF-AT during B cell stimulation through the CD40 receptor. Int Immunol 1995; 7:151-61.

33 Foey AD, Feldmann M, Brennan FM. Route of monocyte differentiation determines their cytokine production profile: CD40 ligation induces interleukin 10 expression. Cytokine 2000; 12:1496-505.

34 McDyer JF, Goletz TJ, Thomas E, June CH, Seder RA. CD40 ligand/ CD40 stimulation regulates the production of IFN-gamma from human peripheral blood mononuclear cells in an IL-12- and/or CD28dependent manner. J Immunol 1998; 160:1701-7.

35 Campos-Neto A, Ovendale P, Bement T, Koppi TA, Fanslow WC, Rossi MA, Alderson MR. CD40 ligand is not essential for the development of cell-mediated immunity and resistance to Mycobacterium tuberculosis. J Immunol 1998; 160:2037-41.

36 Samten B, Thomas EK, Gong J, Barnes PF. Depressed CD40 ligand expression contributes to reduced gamma interferon production in human tuberculosis. Infect Immun 2000; 68:3002-6.

37 Saunders BM, Frank AA, Orme IM. Granuloma formation is required to contain bacillus growth and delay mortality in mice chonically infected with Mycobacterium tuberculosis. Immunology 1999; 98:3248 .

38 Johnson CM, Cooper AM, Frank AA, Orme IM. Adequate expression of protective immunity in the absence of granuloma formation in Mycobacterium tuberculosis-infected mice with a disruption in the intracellular adhesion molecule 1 gene. Infect Immun 1998; 66:166670.

39 Kim JJ, Tsai A, Nottingham LK et al. Intracellular adhesion molecule1 modulates beta-chemokines and directly costimulates $\mathrm{T}$ cells in vivo. J Clin Invest 1999; 103:869-77.

40 Condos R, Raju B, Canova A, Zhao BY, Weiden M, Rom WN, Pine R. Recombinant gamma interferon stimulates signal transduction and gene expression in alveolar macrophages in vitro and in tuberculosis patients. Infect Immun 2003; 71:2058-64.

41 Condos R, Rom WN, Liu YM, Schluger NW. Local immune responses correlate with presentation and outcome in tuberculosis. Am J Respir Crit Care Med 1998; 157:729-35.

42 Law KF, Jagirdar J, Weiden MD, Bodkin M, Rom WN. Tuberculosis in HIV-positive patients: cellular response and immune activation in the lung. Am J Respir Crit Care Med 1996; 153:1377-84.

43 Ito S, Ansari P, Sakatsume M, Dickensheets H, Vazquez N, Donnelly RP, Larner AC, Finbloom DS. Interleukin-10 inhibits expression of both interferon alpha- and interferon gamma- induced genes by suppressing tyrosine phosphorylation of STAT1. Blood 1999; 93:1456-63.

44 Ting LM, Kim AC, Cattamanchi A, Ernst JD. Mycobacterium tuberculosis inhibits IFN-gamma transcriptional responses without inhibiting activation of STAT1. J Immunol 1999; 163:3898-906.

45 Tobian AA, Potter NS, Ramachandra L, Pai RK, Convery M, Boom WH, Harding CV. Alternate class I MHC antigen processing is inhibited by Toll-like receptor signaling pathogen-associated molecular patterns. Mycobacterium tuberculosis 19-kDa lipoprotein, CpG DNA, and lipopolysaccharide. J Immunol 2003; 171:1413-22.

46 Noss EH, Pai RK, Sellati TJ, Radolf JD, Belisle J, Golenbock DT, Boom WH, Harding CV. Toll-like receptor 2-dependent inhibition of macrophage class II MHC expression and antigen processing by 19kDa lipoprotein of Mycobacterium tuberculosis. J Immunol 2001; 167:910-8.

47 Fortsch D, Rollinghoff M, Stenger S. IL-10 converts human dendritic cells into macrophage-like cells with increased antibacterial activity against virulent Mycobacterium tuberculosis. J Immunol 2000; 165:978-87.

48 De Smedt T, Van Mechelen M, De Becker G, Urbain J, Leo O, Moser M. Effect of interleukin-10 on dendritic cell maturation and function. Eur J Immunol 1997; 27:1229-35. 